\title{
Empowerment of small and medium (SMEs) enterprises through the provision of credit with the guarantee of movable objects
}

\author{
Syarifah Lisa Andriati* and Tan Kamello \\ Doctoral Program in Law, Graduate School, Universitas Sumatera Utara, Medan, Indonesia
}

\begin{abstract}
Small and medium enterprises have an extremly important position in national economy and social life. Especially when it is associated with the economic empowerment of the community and the amount of labor that the small and medium enterprises can absorb. In addition to having a strategic meaning for development, small and medium enterprises also serve as a means to state the results of development that has been achieved. Empowerment of Small and Medium Enterprises (SMEs) is usually accompanied by capital needs. One of the obstacles faced by SMEs in developing their business related to the weakness of capital structure and lack of access to strengthen the capital structure. There is a need for a legislation that regulates related to the granting collateral of movable objects to facilitate SMEs regarding capital loans.
\end{abstract}

\section{Introduction}

The national development aims to create a just and prosperous society which is evenly and spiritually based on the Pancasila of the 1945 Constitution, especially in the economic field can be seen by increasing national production, opening employment opportunities, maintaining financial stability, abroad in order not to deficit, to seek an increase in domestic income and equal distribution of income. [1]

Pancasila and the 1945 Constitution of the State of the Republic of Indonesia is the primary philosophy underlying the activities of the state and nation especially in the economic development of Indonesia. In Article 33 of the 1945 Constitution of the State of the Republic of Indonesia, the foundation for the implementation of the national economy states that the economy is compiled and developed as a sustainable joint effort of all people based on the principles of justice, efficiency and economic democracy to bring prosperity, prosperity and social justice for all Indonesian people.

Small and medium business sector plays a significant role in building the economy of society. This is especially when it is associated with the economic empowerment of the community and the amount of labor that the small and medium enterprises can absorb. In addition to having a strategic meaning for development, small and medium enterprises also

*Correspondent Author: Syarifah_lisa_andriati@usu.ac.id 
serve as a means to state the results of development that has been achieved. Central Bureau of Statistics (BPS) defines SMEs based on labor quantity.

From BPS data and Ministry of Cooperatives, from all business class shows that small scale business in Indonesia occupies about $99 \%$ portion, almost means all market in Indonesia is a small business, only $1 \%$ only medium and big business. The growth and growth of SMEs are quite good from year to year. Almost every government emphasizes the empowerment of SMEs. [2]

Table 1. SMEs classification based on Law no. 20/2008

\begin{tabular}{|l|l|l|}
\hline Value Of Bussiness & Assets & Turn Over \\
\hline Micro Bussiness & Minimal 50 Millions & Maximal 300 Millions \\
\hline Small Bussiness & $>50$ Millions -500 Millions & Maximal 3 Billions \\
\hline Average Bussiness & $>500$ Millions-10 Billions & $>2,5-50$ Millions \\
\hline
\end{tabular}

Sources : UU No.20 years 2008

One of the obstacles faced by SMEs in developing their business related to the weakness of a capital structure and lack of access to strengthen the capital structure. There are still many perpetrators of SMEs who have difficulty obtaining credit access from banks, for example, do not have enough collateral. [3]

Business actors of SMEs have not realized their role optimally in the national economy. Therefore, to achieve the function and development of SMEs should be supported by financing, especially banking credit. If there is no role of government in regulating the regulation related to the funding especially banking credit, it is feared SMEs will have difficulties in capital so that cannot develop its business.

\section{Problem}

The problem in this study: how to empower SMEs through the provision of credit with a guarantee?

\section{Research methods}

This research applied a normative legal approach. A normative legal method is a legal research that treats law as a norm system. The data was secondary data consisting of: a) primary legal materials in the form of legislation; b) secondary legal materials in the form of writings, both in the form of books and articles containing comments or analysis related to the subject matter; c) tertiary legal materials in the form of dictionaries. The data was collected using a literature review and document analysis. The data was analyzed using a qualitative method based on deductive reasoning.

\section{Discussions}

\subsection{The economic system in Indonesia}

Indonesia is a legal country. Therefore, the financial system must also refer to Pancasila and the 1945 Constitution which became Pancasila Economic System namely the economic system that is imbued by Pancasila and based on the 1945 Constitution. [4] In the financial order of Pancasila industrial relations among economic actors based on ethical or moral Pancasila with the ultimate goal of realizing social justice for all Indonesian people. [5]

Ningrum Natasya Sirait argues that at present there is not a single country free of the issues concerning politics, economics and democratization efforts, although the level of the 
problem is different from one another. Of the various economic systems that exist, then each country will implement a system that is considered appropriate and in accordance with the national interests of the country. [6]

Therefore Zweigert and Kortz interpret ideology as a legal system as the meaning of political or economic doctrine or religious belief. Fukuyama in his book says in most regions of the world, now there is no more ideology with pretense to the universality that is in a position of challenging liberal democracy and no longer the principle of universal legitimation except the sovereignty of the people. [7]

The patterns of global migration, both old and new, and the exchange between different countries, economies, societies and legal systems, varying degrees and through various methods over time have created a cross-national legal environment that is naturally plural, multi-ethnic and multicultural, increasingly emerging in today's reality. [8]

In economic system with the fundamental principle of economic democracy trying to avoid free liberal financial system, command economy system and unhealthy competition. [9]. Pancasila Economic System or also called the populist financial system is generally interpreted as a system that combines constitutional ideology (Pancasila and the 1945) of the Indonesian nation with a mixed economic system (managed market economic system) embodied through democracy as well as described in the financial steps that are aligned and empowerment of all layers of a just and prosperous society. [10]

In the regulation Small and Medium Enterprises also adheres to the principles of economic democracy. In the Elucidation of Article 2, it states that the law of economic freedom is the empowerment of micro, small and medium enterprises held as a unity of national economic development to realize the prosperity of the people. And Article 3 of Law No.20 Year 2008 on Micro, Small and Medium Enterprises which states that micro, small and medium enterprises aims to grow and develop business in order to build a national economy based on a just economic democracy.

\subsection{Funding Credit SMEs}

Indonesia is still at the level of developing countries, is actively building the economy through micro, small and medium enterprises (SMEs). Various policies made by the government to continue to encourage the growth and development of SMEs one of them in the field of capital.

In Indonesia, the definition of SMEs is regulated under the Law of the Republic of Indonesia Number 20 the Year 2008 on Micro, Small and Medium Enterprises. Definitions according to Law no. 20 of 2008 are: (1) Micro Business is productive business owned by individual and individual business entity fulfilling the criteria of Micro Business as regulated in this Law. (2) Small-scale industry shall be a stand-alone productive economic enterprise, carried out by an individual or business entity which is not a subsidiary or not a branch of a company owned, controlled, or a part, directly or indirectly, of a medium-sized or largefulfill the criteria of Small Business as referred to in the Law; (3) Medium-sized Enterprises shall be stand-alone productive economic enterprises, carried out by an individual or business entity which is not a subsidiary or branch of a company owned, controlled, or partakers either directly or indirectly with a small or large-scale business by the amount net worth or annual sale proceeds as stipulated in the Act.

In the Salmek Saragih Research, Tan Kamello et al. Argues that the procedure of credit granting cooperatives and small businesses still consider it quite complicated; it is indicated by the many stages that must be passed. Micro, Small and Medium Enterprises generally rely on their capital in running their business, and sometimes they are caught in the lenders' attachment given the lack of accessibility to formal financing sources. [11] 
In his research entitled "Development and Strategy of SMEs Financing," Lestari mentioned some obstacles experienced by SMEs in fulfilling their capital needs. One of the barriers is the complexity of procedures that must be undertaken so that SMEs increasingly difficult to get credit from the banks. It is necessary to improve the system of credit procedures from the financial institution so that SMEs can feel credit facilities.

Loans given by the bank are based on trust, thus crediting is a gift to the customer. Ability to execute a grant or enter into a loan with a pledge whose payments will be made within an agreed timeframe. According to Law Number 10 the Year 1998 concerning Banking, the Bank is a business entity that collects funds from the public in the form of savings and distributes to the community in the way of credit and other types to improve the standard of living of the people. One form of channeling of funds is to provide credit to the community. Bank as a guarantee in lending based on confidence, besides doing penicillin to debtor based on 5C that is: character, capacity, capital, collateral, condition. [12]

Credit also provides protection to economically weak groups in the development of their business. The credit sector is one means of capital generation for the business community. For banks, every gift distributed to entrepreneurs always carries risks. Therefore, the need for security elements in return. In terms of convincing the bank that the customer is truly trustworthy, then before the credit is given in advance the bank conducts credit analysis. Credit analysis includes the background of the customer or the company, its business prospects, guarantees and other factors. The purpose of the study is for the bank to be confident that the credit provided is entirely secure. [13]

The security element is one of the primary principles in lending credit other than the aspect of suitability and profitability. Banks also always ask for collateral or collateral. The form of securing credit in banking practice is done by binding of the guarantee. Guarantees have essential positions and benefits in supporting economic development. Because the existence of this institution can provide benefits to creditors and debtors. The creditor's interest is the realization of security against closed trading transactions as well as providing legal certainty for creditors. [14]

Rachmadi Usman argues that general guarantees are addressed to all creditors and to all debtor properties. Each creditor has the same right to obtain debt repayment from the proceeds of sale of all material possessed by the debtor. [15] About the guarantee as a grant of security of funds or credit then in broad outline there are two kinds of warranties, namely individual guarantees and real guarantees. The most preferred guarantee by the bank and the other party as the creditor is the guarantee of materiality.

In the development of the Indonesian economy, credit guarantee is one of the solutions needed by micro and small enterprises to obtain banking credit facilities. In essence, credit guarantee is required as a fulfillment of technical requirements for micro and small enterprises that have an excellent prospective business, but not enough assurance so that technically does not fulfill credit requirement from a bank. In other words, credit guarantee is a bridge for those who are feasible, but not yet bankable. [16]

The debtor is not able to return the principal of credit and interest, the bank or the owner of the capital may execute against the guarantee object. The value of the corresponding object is usually at the time of making the estimated cost higher when compared to the principal of interest in arrears. However, for SMEs material security in the form of land is very burdensome for SMEs who do not have property or certificate. Therefore, regarding providing convenience in providing collateral then by merely moving goods owned by SMEs such as cars, inventory, machinery and so forth.

\section{Conclusions}


Capital needs usually accompany the development of Small and Medium Enterprises (SMEs). In the case of capital loans from banks always apply the various requirements of credit security guarantees channeled which is often requested by the Bank in the form of material security with the guarantee of the land. This case is very burdensome SMEs. There is a need for a legislation that regulates related to the granting collateral of movable objects to facilitate SMEs regarding capital loans for example Bank Indonesia regulation.

\section{References}

1 Hafni R. Tujuan Pembangunan Nasional dan Pertumbuhan Ekonomi. Diakses dari http://www.materisma.com/2014/09/tujuan-pembanguan-nasional-dan-ekonomi.html, (2014).

2 BPS, Retrieved December, $26^{\text {th }} 2017$, from http://www.bps.go.id

3 BI Retrieved March, $3^{\text {rd }} 2018$ from http://www.bi.go.id/umkm/kelayakan/Contents/Default.aspx

4 M. Siregar, Hukum Ekonomi Indonesia dan Pembangunan Nasional, dalam Butir-Butir Pemikiran Guru Besar dari Masa ke Masa, Pidato Pengukuhan Jabatan Guru Besar Fakultas Hukum USU 1979-2001, penyunting Tan Kamello Pustaka Bangsa Press, Medan, (2003).

5 Mubyarto, Moral Ekonomi Pancasila, (Yayasan Idayu, Jakarta, 1982).

6 N.N. Sirait, Indonesia dalam Menghadapi Persaingan Internasional, Pidato Pengukuhan Guru Besar Tetap dalam Bidang Ilmu Hukum Internasional, Universitas Sumatera Utara, Medan, (2006)

7 P. de Cruz, Perbandingan Sistem Hukum Common Law, Civil Law dan Socialist Law, (Nusamedia, Jakarta, 2017)

8 W. Menski, Perbandingan Hukum Dalam Konteks Global, Sistem Eropa, Asia dan Afrika, (Nusamedia, Bandung, 2016).

9 A. Madjid dan S. E. Wasono, Wawasan Ekonomi Pancasila, (Universitas Indonesia Press, Jakarta, 1988)

10 J. Assiddiqie, Konstitusi Ekonomi, (Kompas, Jakarta, 2010).

11 S. Saragih, Tan Kamello dkk. "Melakukan kajian pemberian kredit modal bergulir untuk koperasi dan usaha kecil dalam rangka pemberdayaan ekonomi rakyat di Sumatera Utara", Mercatoria 1, (1) (2008).

12 M. Djumhana, Hukum Perbankan Indonesia, (Citra Aditya Bakti, Bandung, 1997).

13 Kasmir, Dasar-dasar Perbankan, (Raja Grafindo Persada, Jakarta, 2000)

14 T. Kamello,Hukum Jaminan Fidusia: Suatu Kebutuhan yang didambakan, Alumni, Bandung, (2004).

15 R. Usman, Hukum Jaminan Keperdataan, (Sinar Grafika, Jakarta, 2008).

16 E. Mulyati, Kredit Perbankan: Aspek Hukum dalam Pengembangan Usaha Mikro Kecil dalam Pembangunan Perekonomian Indonesia,(Refika Aditama, Bandung, 2016). 